\title{
THE MEASUREMENT MODEL OF HISTORICAL AWARENESS
}

\author{
$*^{1}$ Aisiah; ${ }^{2}$ Suhartono; ${ }^{3}$ Sumarno \\ ${ }^{1}$ Faculty of Social Sciences, Universitas Negeri Padang, Jln. Prof. Dr. Hamka, Air Tawar, Padang, \\ 25131, Sumatera Barat, Indonesia \\ ${ }^{2}$ Faculty of Cultural Sciences, Universitas Gadjah Mada, Jl. Nusantara 1, Bulaksumur, \\ Caturtunggal, Depok, Sleman, 55281, Yogyakarta, Indonesia \\ ${ }^{3}$ Graduate School of Universitas Negeri Yogyakarta, Jl. Colombo No. 1, Karangmalang, \\ Caturtunggal, Depok, Sleman, 55281, Yogyakarta, Indonesia
}

\begin{abstract}
The study aimed to develop a measurement model of historical awareness through a research and development model adopted from the Plomp model. Historical awareness was measured through four components, namely: knowledge of historical events, understanding of historical research method, meaning of historical events, and usefulness of history. The development procedures of the development model included a preliminary investigation in the form of literary study about the constructs of historical awareness. In the design stage, the researcher designed a conceptual model and a hypothetical measurement model about historical awareness. Then, the researcher performed a test construction namely assembling the test instrument for measuring historical awareness. Eventually, the researcher administered a test, did evaluation and made revision. The test in the study referred to the empirical testing of the instrument, while the evaluation in the study referred to the efforts to identify the obstacles that the participants encountered within the empirical testing of the instrument in order to revise it. The empirical testing of the instrument involved history teacher-candidates at Universitas Negeri Yogyakarta and Universitas Negeri Padang. The data were gathered through the test by using the measurement instrument in the form of associative multiple choice test. For the construct analysis, the researcher implemented confirmatory factor analysis by means of Lisrel 8.80 program. The results of the analysis show that the $\chi^{2}=121.98$, the $\mathrm{p}$-value $=0.11$, RMSEA $=0.043$. In other words, the measurement model of historical awareness that had been developed was supported by the empirical data.
\end{abstract}

Keywords: historical awareness, measurement model, knowledge of historical event, historical research method, meaning of historical event, usefulness of history

\section{How to cite item:}

Aisiah, A., Suhartono, S., \& Sumarno, S. (2016). The measurement model of historical awareness. Research and Evaluation in Education, 2(2), 108-121. doi:http://dx.doi.org/10.21831/reid.v2i2.8399

*Corresponding Author.

e-mail: aisiah.unp@gmail.com 


\section{Introduction}

This article reviews the measurement model of historical awareness. The intended measurement model is an effort to make a measurement model from a latent variable (historical awareness) through components or indicators presented in the form of a path diagram. The concept of historical awareness is defined as a condition or a reasoning process in which people recall the meaning and the usefulness of history. The constructs or the components of historical awareness include four aspects, namely: Knowledge of Historical Events (Pengetabuan Peristiwa Sejarah, PPS), Understanding of Historical Research Method (Pemahaman Metode Penelitian Sejarah, PMPS), Meaning of Historical Events (Pemaknaan Peristiwa Sejarah, MPS) and Usefulness of history (Kegunaan Sejarah, GS). The four constructs of historical awareness are derived from the ideas of Indonesian historians such as Soedjatmoko, Ruslan Abdulgani, and Sartono Kartodirdjo. Threfore, ideas and a theoretical review regarding historical awareness are constructed and elaborated as follows.

Historical awareness is possessed only by human beings and, therefore, it has frequently been said that human beings are historical creatures. Heller (1982, p.3) asserts that it is human beings throughout the world who can tell their history because human beings are those who understand the concept of 'once upon a time.' Human beings review and analyze their life history and their nations. The nations that do not understand their history look like individuals who have lost their memories (suffering from amnesia/ senile dementia) so that they should search to find their identity throughout the darkness (Kartodirdjo, 1993, p.50; Hariyono, 1995, p.1). In other words, a nation that does not have historical awareness is a nation that has lost its identity. Therefore, historical awareness should always exist in every citizen as the generation of a nation.

Every citizen should develop historical awareness in his or her nation and state life (Rosenlund, 2011, p.1). The effort to develop historical awareness among the generation of a nation might be pursued by means of histo- ry education (history teaching). Kartodirdjo (1993, p.51) asserts that historical subject has a socio-cultural function to encourage historical awareness. Historical awareness is a key concept that has been very important and significant in historical didactic (Thorp, 2014, p.iv; Korber, 2015, p.1). People who are studying history will have the ability to compare the difference among periods, cultures and social systems (Ata, 2009, p.8). This ability is the manifestation of an individual's historical awareness.

The teaching of history recently has not been successful in developing the historical awareness of young generation. The condition needs a very serious attention. In the university for example, there are some university students who have not understood and even comprehended the important meanings of their nation's history (Ministry of Education and Culture, 2012, p.54). The emphasis on the factual knowledge is certainly 'dry' and does not cover much of university students' understanding of the exemplary values that are studied or researched in their final assignment. According to Mardapi (2007, p.5), the teaching quality might be viewed from the assessment results. Both aspects are related to one another and there should be continous improvement efforts.

The assessment of historical awareness of history teacher candidates seems to be missed from most lecturers' attentions. Historical awareness reflects the internalization (Wineburg, 2006, p.48) of life values and the nationality that is reflected in historical events taught by history teacher candidates at university. In order to measure the condition of historical awareness of history-teacher candidates, there should be a valid and reliable measurement instrument.

The measurement of historical awareness level among history-teacher candidates at university becomes an urgent demand regarding the fact that these history-teacher candidates will be history-teachers who should grow historical awareness among the students at middle school. Therefore, this study is intended to develop a measurement model of historical awareness. 


\section{Constructs of Historical Awareness}

Lukacs (1968, p.15) defines historical awareness simply as the past that has been recalled (remembered past); meanwhile, Paska (2010, p.7) defines historical awareness in a more in-depth manner such how people view the past. Historical awareness is a fundamental ability to recall and imagine the past events (Kolbl \& Straub, 2001, p.8). According to Lukacs (1968, pp.9-10), recalling the past involves cognition and recognition that are closely related to the reasoning process or activities. For Ankersmit (1987, p.354), historical awareness as the reasoning process is marked by an awareness that the past depiction as an intellectual discourse associated to the particular factual accuracy.

The constructs of historical awareness from the ideas and thoughts of several Indonesian historians regarding the concept of historical awareness are formulated. Their thoughts and ideas are presented in Table 1.

According to Abdulgani (Ministry of Education and Culture, 2012, p.43), the definition of historical awareness is as follows:

Historical awareness is a mental attitude ... that has been the strength to take active participation in bistory dynamics. Historical awareness includes: first, the knowledge of historical facts and their causal relationship (the cause and effect among the historical facts); second, the loading of our mind with the logics, namely the existence of certain laws in bistory; and third, the improvement of our conscience by wisdom and intelligence in order to reflect from the past experiences.

Abdulgani views historical awareness in relation to the knowledge, meaning, and usefulness of history. According to Soedjatmoko (Ministry of Education and Culture, 2012, p.43), the concept of historical awareness is related to the mental attitude, but it is more emphasized on the way an individual puts himself in front of the social truth and reality within the perspective of present, past, and future. According to Lapian (Ministry of Education and Culture, 2012, p.42), historical awareness is defined as historical clarification namely a study of: elementary matters such as who, what, when, where and why; the impression of history and the function of history in education.

Leirissa (Ministry of Education and Culture, 2012, p.41) tends to simplify Lapian's idea regarding historical awareness; in his opinion, historical awareness serves as an understanding of the essence of the historical study. Ayatroehadi (Ministry of Education

Table 1. The historians' ideas and thoughts regarding the concept of historical awareness

\begin{tabular}{|c|c|c|}
\hline Historians & Definition of historical awareness & $\begin{array}{c}\text { Construct } \\
\text { conclusion }\end{array}$ \\
\hline $\begin{array}{l}\text { Ruslan } \\
\text { Abdulgani }\end{array}$ & $\begin{array}{l}\text { Historical awareness has been a mental attitude (strength) that covers the } \\
\text { knowledge of historical facts and their causality, the historical logic and the } \\
\text { improvement of conscience by wisdom and intelligence for reflecting the } \\
\text { past. }\end{array}$ & \multirow{2}{*}{$\begin{array}{l}\text { 1. Knowledge of } \\
\text { Historical } \\
\text { Events } \\
\text { 2. Understanding } \\
\text { of Historical } \\
\text { Research } \\
\text { Method }\end{array}$} \\
\hline $\begin{array}{l}\text { Sartono } \\
\text { Kartodirdjo }\end{array}$ & $\begin{array}{l}\text { Historical awareness will be improved by possessing historical knowledge, } \\
\text { historical mindedness and by being able to imagine the situation of past } \\
\text { history, cultural atmosphere, sentiment, idea, mentality, life style etc. }\end{array}$ & \\
\hline Soedjatmoko & $\begin{array}{l}\text { Historical awareness has been a mental attitude and a manner to put } \\
\text { oneself in front of the truth and the social reality in the perspective of } \\
\text { present, past, and future. }\end{array}$ & $\begin{array}{l}\text { 3. Meaning of } \\
\text { Historical } \\
\text { Events }\end{array}$ \\
\hline $\begin{array}{l}\text { Adrian } \\
\text { Bernard } \\
\text { Lapian }\end{array}$ & $\begin{array}{l}\text { Historical awareness is not independent on clarification, namely a historical } \\
\text { study that entails the elementary aspects such as who, what, when, where } \\
\text { and why, the historical impression, and function in the education and the } \\
\text { controversial aspects. }\end{array}$ & \multirow[t]{3}{*}{$\begin{array}{l}\text { 4. Usefuness of } \\
\text { History }\end{array}$} \\
\hline $\begin{array}{l}\text { R. Z. } \\
\text { Leirissa }\end{array}$ & Historical awareness is an understanding of the essence of historical study. & \\
\hline Ayatroehadi & $\begin{array}{l}\text { Historical awareness includes insight regarding history, the ideas within the } \\
\text { historical insight, the theoretical and methodological foundation of } \\
\text { historical study and the oral/written review regarding history. }\end{array}$ & \\
\hline
\end{tabular}

Source: Kutoyo in Ministry of Education and Culture (2012) 
and Culture, 2012, p.42) in details view historical awareness as historical insights and ideas including historical knowledge, theoretical foundation and research methodology as well as oral and the written historical reviews.

The ideas of several historians might be summarized into the definition that historical awareness is a condition and reasoning process in which an individual recalls the meaning of history and its usefulness. The meaning of history refers to the terminology of history as past events and history as a science and methodology in historical research/study. Furthermore, another important aspect in historical awareness is understanding the meaning (significant meaning) of historical events in the form of values and impacts of historical events and the usefulness of history in life. Various experiences from past events that have been studied give a certain meaning according to certain interpretation. Eventually, the meaning will direct how history will be used in life.

The constructs of historical awareness are derived from the concept of historical awareness according to historians' thoughts which has been presented in Table 1. The operationalization of the concept of historical awareness is adopted from the reasoning manner of Greenberg (1991, p.7) who states that historical awareness as a conceptual system comprises interactive elements which allows comprehension of temporal/historical experience and individual placement in time/ history.

In other words, historical awareness defined as a conceptual system consists of several aspects and has the function in forming historical awareness. Therefore, in this research, the design of a conceptual system of historial awareness includes four components and this components are the hypothetical constructs in developing the measurement model of historical awareness. The four components as the hypothetical constructs of the measurement model include: (1) knowledge of historical events; (2) understanding of historical method; (3) meaning of historical events; and (4) usefulness of history (see Figure 1).

Figure 1 is the conceptual system of historical awareness consisting of four constructs (components) which become the basis in forming historical awareness. The appearance of historical awareness starts from the knowledge of historical facts and interrelatedness among historical facts (Kartodirdjo, 1986, p.9; Latief, 2006, p.49). Knowledge of historical events is the preliminary requirement for establishing historical awareness and, on the other hand, historical awareness is very important and influences production of historical knowledge (Gleencross, 2010, pp.13). According to Budhisantoso (Ministry of Education and Culture, 2012, p.22), the development of historical awareness should be conducted by expanding historical knowledge and historical comprehension of cultural values of a nation. Historical knowledge cannot be separated from the investigation process or the implementation of a research method.

Historical knowledge is proved by the robustness of historical research findings (Kreuzer, 2010, p.383). The results of historical studies might strengthen historical aware-

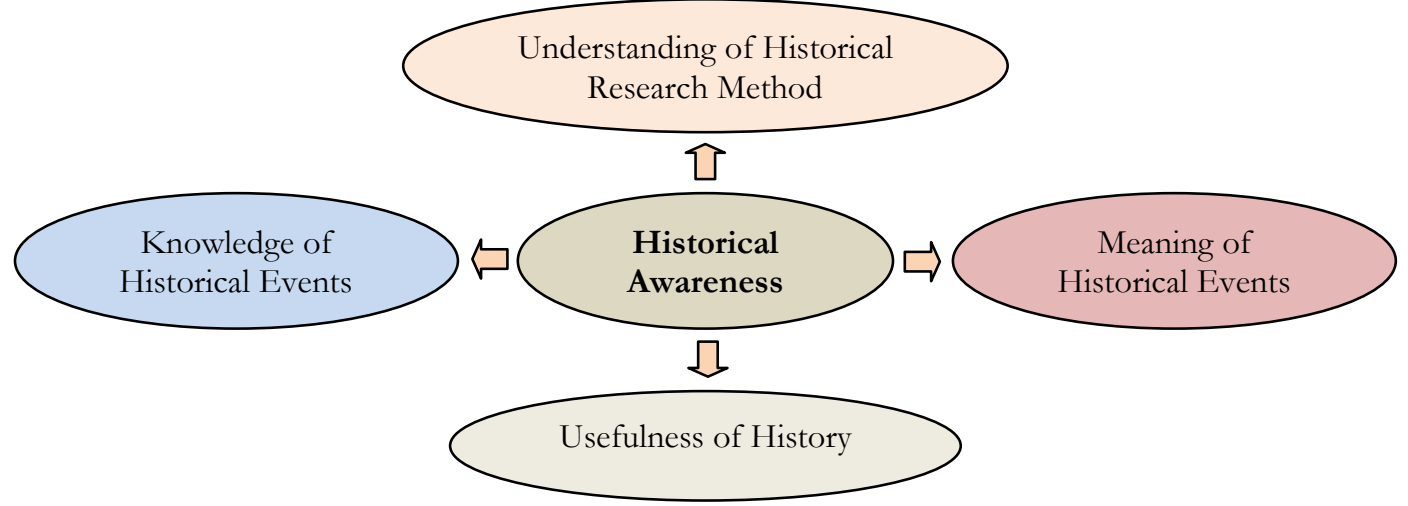

Figure 1. The constructs of historical awareness 
ness and even historical awareness might be the foundation in distinguishing facts from myths (Pompa, 1990, p.217) in the process of historical reconstruction. Historical awareness helps an individual trace the meaning reflected in historical events.

The meaning of historical events lies in the significance that people give to historical events (Denison, 2011, p.47). The significance of historical event is shown by the values that have been reflected in the values that individuals have in the past (Tucker, 2009,p.14) and impacts of those historical events. The ability to explore the significance of historical events and values that historical events contained reflects the depth level of historical awareness. Historical awareness in this level does not solely come from the knowledge of the facts of historical events; instead, historical awareness in this level comes from the deep understanding of the significant meaning of historical events. By recalling the past, an individual might act better in the upcoming future (Pownal, 2007, p.26). The expectation is that an individual will not repeat the same mistake that was made or experienced in the past for the sake of the future.

\section{Knowledge of Historical Events}

Knowledge of historical events is the knowledge about what (event) has occured in the past of human history or the knowledge about historical facts and processes (Topolski, 1976, pp.305-411). The essence of the knowledge of historical events is explanation of historical events together with the overall facts, including 'what,' 'who,' 'when,' 'where', and 'how' (Kartodirdjo, 1992, p.252; Grant, 2003, p.60). The knowledge of histori-cal events does not lie on what aspects might inform the future; instead, the knowledge of historical events lies on what aspects might inform the past (Elliott, 2003, p.24). The knowledge of historical events might be measured through what has been recalled regarding the facts that have been learned (Grant, 2003, p.89).

Intellectual curiosity regarding the matters of the past is one of the reasons why people learn and study history (Tosh, 1984, p.21). Historical knowledge is one of the elements of historical understanding (Grant,
2003, p.58). The historical understanding is viewed from the limits of substantive knowledge and procedural aspects of history disciplines (Husband, Kitson \& Pendry, 2003, p.58). Historical understanding includes an understanding of causality (Kitson, Husband \& Steward, 2011, p.74). The students at the university use and produce information through texts and develop their skills in interpreting historical knowledge and thoughts (Paska, 2010, p.3). University students might put themselves into the consumers and the producers of historical knowledge as they look more deeply into historial studies.

\section{Understanding Historical Research Method}

A historical research method refers to the use of a sequence of scientific procedures to verify historical evidences or sources (Tosh, 2002, p.104). These procedures include topic selection, critics, internal and external criticism, analysis and interpretation and presentation in the form of a composition (Kuntowijoyo, 2013, p.64). The topic selection should be in accordance with the interest of the researchers. After the topic has been selected, the sources are collected (heuristics).

Historical sources are a number of historical materials that might enlight the story of human life/life inheritance and the results of human activities, both physically and nonphysically (Suhartono, 2010, p.29). Historical sources consist of primary and secondary sources. After the historical sources (documents) have been found, there are two aspects that should be investigated, namely the authenticity and the credibility of the sources (Gottschalk, 1956, p.27). This process is called source criticism. A source criticism is a process of verifying or testing the accuracy of historical sources in the form of source appropriateness (Sjamsuddin, 2012, p.102). The source criticism consists of internal and external criticisms. The external criticism refers to the efforts to prove the source authenticity by investigating the physical sources/testing the external aspects of historical sources (Suhartono, 2010, p.6). Through an external criticism, a researcher might identify the originality of historical sources from historical events that are investigated. 
On the other hand, an internal criticism refers to the efforts to investigate the source credibility, whether the sources are trustworthy or not, whether the sources are manipulated or not, whether the sources are biased or not, whether the sources are deceiving or not, and the like, in order to understand the content of historical sources (Suhartono, 2010, pp.36-37). The testing of historical source credibility is a form of second verification (second investigation) for proving whether the historical sources are trustworthy or not (Kuntowijoyo, 2013, p.78). Verification refers to justification, proofing, validation and confirmation for attaining the trustworthy information. The source verification is conducted by asking several logical questions regarding a historical event and by comparing historical events to a number of other data in relation to historical events, so that the researcher can have the objective and reliable data in the process of interpretation.

Interpretation covers two elements: an analysis and a synthesis. An analysis refers to elaboration, while a synthesis refers to unification (Kuntowijoyo, 2013, pp.78-79). After the data have been found, they are then analyzed and, therefore, historical facts can be revealed. People might have different opinions in the analysis and the synthesis. Interpretation is frequently known as the source of subjectivity. This statement might be correct or incorrect. The statement might be correct because without a historian's interpretation the data will not be able to convey any information. On the contrary, the statement might be incorrect if the historian is not honest about the data and the information that he or she has attained. Subjectivity is admitted but should be avoided. Last but not least, the historiography (composition) is the final stage in historical research.

\section{Meaning of Historical Events}

The meaning of historical events for people, objects, and events depends on the value implementation in certain perspectives (Barash, 2003, p.27). Meaning does not appear as a part of fact (Cohen, 1961, p.44). The historical meaning is shown by the historical significance. The effort to train the capacity in building the meaning of a historical event is a matter that exceeds simple knowledge-based content (Russel \& Pellegrino, 2008, p.3). People might define or find the impor-tant meaning or significance of historical events by understanding the complexity of the events.

Wineburg (2006, p.37) asserts that history that is taught well will allow people to have enormous capacity in understanding the meaning that enables them to form the world. Abdullah (Ministry of Education and Culture, 2012, p.10) asserts as well that if historical reconstruction is conducted through a selection, then the establishment of historical awareness will be very selective. The events that belong to historical awareness are processed by the value system that ultimately will be the basis of a historical view. History provides not only meaning but also wisdom.

History does not only memorize the past events, but also understand the meaning of these past events. Questions regarding the historical meaning are those that always appear and are always questioned by human beings (Kartodirdjo, 1986, p.5). History might be said as having historical meaning if it can deliver human being to the discovery of future aspects. Human conscience becomes the basis of self-awareness from the life experiences in which historical meaning is reached (Barash, 2003, p.109). Everyone may protect himself or herself by understanding what he or she has been done before and the significance of his or her action (Cohen, 1961, p.252). Past experiences become a useful guidance for encountering the future.

\section{Usefulness of History}

History has multiple usefulness. People will not learn history if history does not have any usefulness (Kuntowijoyo, 2013, p.15). The usefulness of history might be viewed from theoretical and practical aspects. The theoretical usefulness of history is related to the tendency of learning past events for the sake of intellectual-academic needs (scientific importance) of history (Latief, 2006, p.70). History offers the best materials for intellectuality exercises. By learning and investigating history, an individual will have wide understanding and knowledge. 
All historical knowledge is based on the practical needs of human beings (Mazabow, 2003, p.227). The practical usefulness of historical learning might be viewed from the educational, instructional, inspirational, and recreational aspects. History is useful for the educational aspect and the lesson provision. By learning history, people might find many educational examples in the form of moral actions and attitudes that should be attended and avoided. History is also useful for serving as learning materials (Latief, 2006, pp.70-74; Sjamsuddin, 2012, pp.126-216; Kuntowijoyo, 2013, pp.15-28; Tosh, 1984,p.7). By reading and reviewing history books, people will definitely find the meaning and the significance and the useful lessons from historical events.

History might even be a source of inspiration (Tosh, 1984, p.7). By reading various historical studies (autobiographies and biographies), an individual might attain inspirations where they want to go (Kuntowijoyo, 2013, p.23). The inspiration might take the form of ideas, concepts, spirits, motivation, and sacrifice that make people realize the life obstacles and hindrances that they encounter (Latief, 2006, p.72; Sjamsuddin, 2012, p.216). People might see the past to find the solution for the current problems (Gottschalk, 1956, p.172; Tosh, 1984, p.15). By learning history, people will be creative in encountering the challenges of the century.

History provides opportunities to learn from the past experiences. History has been the records of human experiences and human beings might obtain advantages from the multiple domain of science by learning past experiences (Gottschalk, 1956, p.30). History also provides enjoyment that gives the esthetical sense, which opens heart and feelings (Kuntowijoyo, 2013, p.25). The type of historical work in the form of biography might be turned into a joyful reading material that drives people to enjoy the nostalgic moments of the past experiences (Latief, 2006, p.74; Tosh, 1984, p.9). By visiting historical sites, people might sense the beauty of the life conditions in the past.

The past experiences become the mirrors to view the future and compass to get to advancement. History is a set of experiences that become the basis for projecting the future and for predicting the upcoming events (Tosh, 1984, pp.1-4; Greenberg, 1991, p.38). The past experiences relevant to the present experiences in history will be the basis for formulating the actions toward the future (Tosh, 1984, p.21). The historical knowledge is useful as a matter of assistance for interpreting the future (Sjamsuddin, 2012, p.139) and also for equipping human beings with the discovery of recent awareness as well as for serving as the basis in projecting the recent abstraction (Latief, 2006, p.45). Past experiences also become the basis for anticipating every single possibility that might occur in the future.

\section{Measurement Model of Historical Awareness}

Measurement is assigning of numbers to individuals in systematic ways as a means of presenting properties of the individuals or an object (Allen \& Yen, 1979, p.2; Mardapi, 2012 , p.5). The condition of an individual under measurement in the domain of education is usually related to the learning results. In historical learning, the measurement of learning results might be directed to the measurement of historical awareness because it is one of the historical learning results. The measurement of historical awareness should be conducted in a specific model since there are so many aspects that should be learned and contributed to establishing historical awareness as having been described from the theoretical constructs regarding historical awareness.

A measurement model shows the relationship between one observed variable (indicator/response) to another that becomes representation of a latent variable (Schumacker \& Lomax, 2010, p.114; Khine, 2013, pp.5-7). Ghozali (2008, p.127) states that a measurement model describes how good the indicators can be used as the measurement factors of latent variables (construct latent) such as knowledge, behaviors, and attitudes.

Hendryadi (2014, p.63) asserts that a measurement model is an effort to create measurement modelling from the latent variables through dimensions or indicators. In more detail, Kusnendi (2008, p.98) states that a measurement model as a form of variable operationalization or research constructs be- 
comes the measurable indicators that will be formulated into a certain path diagram. Khine (2013, p.6) states that in a wider sense, a measurement model determines how a theory will be operationalized as latent and observed variables.

In this study, the design of the measurement model is developed from the theoretical knowledge/the empirical study and then hypothesizes the relationship pattern between observed and latent variables. Next, the hypothetical model was tested statistically by means of empirical data. Theory plays an important role in the construction of the measurement model (Khine, 2013, p.41). The measurement model of historical awareness is developed based on the results of the theoretical review of historical awareness. Four components of historical awareness in the model have been found (see Figure 1).

The results of the theoretical review show that historical awareness is established by four aspects: knowledge of historical events, understanding of the historical research method, the meaning of historical events, and the usefulness of history. The indicators of each aspects is presented in Table 2. The theoretical constructs of the com-ponents and indicators of historical awareness become the basis of the developed hypothetical masurement model, as presented in Figure 2.

Table 2. Components and indicators of historical awareness

\begin{tabular}{ll}
\multicolumn{1}{c}{ Components } & \multicolumn{1}{c}{ Indicator } \\
\hline a. Knowledge of Historical & $\begin{array}{l}\text { Understanding the facts of historical events, including: what (event), who } \\
\text { (figure), when (period), where (place) and why (cause) }\end{array}$ \\
$\begin{array}{ll}\text { b. Understanding of Historical } \\
\text { Research Method }\end{array}$ & $\begin{array}{l}\text { Identifying the procedures of conducting historical research, including: } \\
\text { heuristics, criticism, verification, interpretation and historiography }\end{array}$ \\
c. Meaning of Historical & Finding the positive impact, the negative impact and the positive values of \\
Events & historical events \\
d. Usefulness of history & $\begin{array}{l}\text { Identifying the usefulness of history theoretically and practically (instructional, } \\
\text { educational, inspirational, recreational and predictional usefulness) }\end{array}$
\end{tabular}

Source: Lukacs, 1968; Kartodirdjo, 1986, 1992, 1993; Ministry of Education and Culture, 2012; Sjamsuddin, 2012

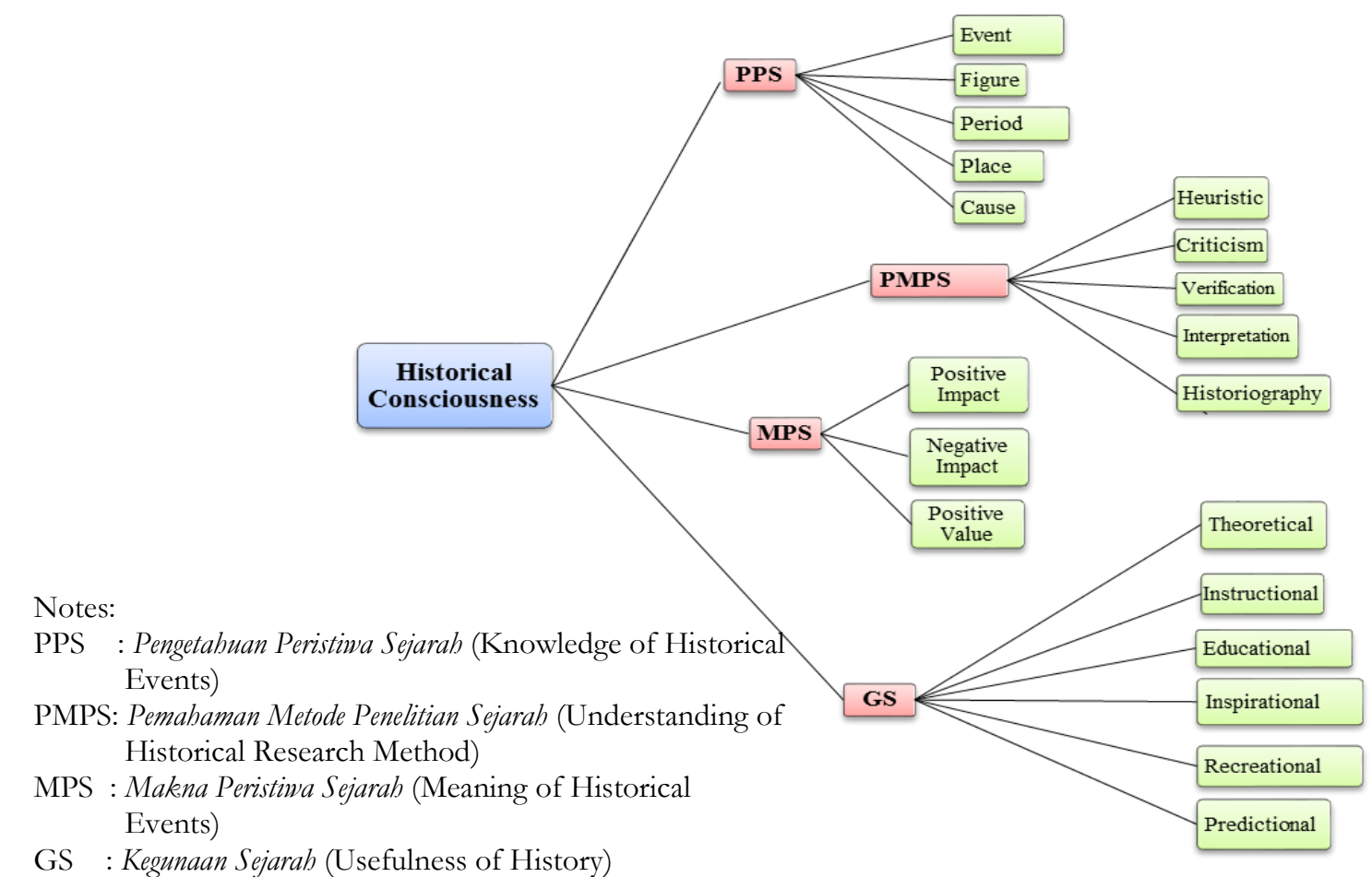

Figure 2. The hypothetical measurement model of historical awareness 


\section{Method}

This study implemented the research and development method adapted from the model proposed by Plomp (1982, p.5). The procedure of the development of measurement model of historical awareness included preliminary investigation (literature study), design (formulating construct and hypothetical diagram of measurement model of historical awareness), construction (making the measurement instrument) and testing (empirical testing of the instrument).

Data gathering was conducted through empirical testing. The developed instrument of historical awareness was an associative multiple-choice test which was designed for history-teacher candidates as the research subjects in empirical testing. The subjects involved history-teacher candidates at two universities: Universitas Negeri Yogyakarta and Universitas Negeri Padang. The sample was established by using stratified random sampling technique involving the first, third, and fifth semester students in the Academic Year of 2014/2015. The total subjects in the empirical testing were 190 history teachercandidates.

Table 3. Details of research subjects

\begin{tabular}{|c|c|c|c|c|c|c|}
\hline \multirow{2}{*}{$\begin{array}{l}\text { University } \\
\text { Semester }\end{array}$} & \multicolumn{2}{|c|}{$\begin{array}{c}\text { Universitas } \\
\text { Negeri } \\
\text { Yogyakarta }\end{array}$} & \multicolumn{3}{|c|}{$\begin{array}{c}\text { Universitas } \\
\text { Negeri } \\
\text { Padang }\end{array}$} & \multirow[t]{2}{*}{ Total } \\
\hline & I & $\mathbf{V}$ & I & III & $\mathbf{V}$ & \\
\hline Total & 45 & 27 & 28 & $\begin{array}{l}48 \\
118\end{array}$ & 42 & 190 \\
\hline
\end{tabular}

Source: Field data

The data were analyzed through the confirmatory factor analysis by using software Lisrel 8.80. This analysis was used to estimate the validity, reliability, and model fitness formulated from the results of the theoretical review. Khine (2013, p.6) asserts that the confirmatory factor analysis is frequently implemented in the measurement model testing. The validity and reliability of the measurement model is shown by the validity and reliability of the measurement instrument that has been tested. The construct validity was measured from the loading factor value resulted from the factor analysis. An observed variable might be considered valid for the construct of the measurement (the latent variable) if the loading factor values was above 0.3 (Schumacker \& Lomax, 2010, p.185). Then, the construct reliability was from the number of standard square of loading factor from each indicator and the number of error variances $\left(\sum e_{j}\right)$.

The formula for measuring the value of construct reliability coefficient in a simple manner proposed by Wijanto (2008, p.175) is as follows:

$$
\text { Construct Reliability }=\frac{\left(\sum \text { std.loading }\right)^{2}}{\left(\sum \text { std.loading }\right)^{2}+\sum \theta_{j}}
$$

\section{Findings and Discussions}

The focus of the measurement model development of historical awareness is to test the validity and reliability of the instrument constructs designed and to test the goodness of fit of the measurement model tested. The objective of the development is to obtain empirical evidence regarding the factors and indicators existed in the measurement model of historical awareness.

The constructs of the measurement instrument that was hypothesized consist of four factors and 19 indicators. The total number of the test items is 90 . The result of the confirmatory factory analysis shows that out of 90 items under analysis, there are 28 items that are invalid and insignificant (loading factor $<0.3$ and $\mathrm{t}$-value $<1.96)$. The invalid test items are eliminated before doing the reanalysis conducted through the modification in accordance with the suggestions existed in the Lisrel software. The goodness of fit model is obtained from that. The distribution of the changes on the items of the historical awareness test after the process of reanalysis is presented in Table 4.

The testing of goodness of fit upon the measurement model of historical awareness that had been tested prioritized to the commonly used one, including Goodness of Fit (GOF) by viewing Chi-Square $\left(\chi^{2}\right)$ value (the smaller $\chi^{2}$ value, the better the result would be) and the probability value ( $\mathrm{p}$-value) $\geq 0.05$, RMSEA $\leq 0.08$ (Wijanto, 2008, pp.54-62; 
Hair, Black, Babin, \& Anderson, 2009, p.22). The results of the second order confirmatory factor analysis ( $2^{\text {nd }}$ order CFA) show that the measurement model of historical awareness is supported by the empirical data based on the $\mathrm{p}$-value criteria $(\leq 0.08)$. These findings prove that the measurement model of historical awareness shows goodness of fit model and the hypothetical model is accepted. Thereby, the measurement model of historical awareness resulted from the theoretical review is supported by empirical data. The measurement model of historical awareness resulted from the empirical testing is presented in Figure 3.
An important aspect that should be given attention to the measurement model is related to the validity and reliability of the measurement instrument constructs. The validity and reliability of the historical awareness measurement model are shown by the value of loading factor in each indicator of four latent constructs of historical awareness. The results of $2^{\text {nd }}$ order CFA as displayed in the Lisrel output (Fig. 3) show that the Standardized Loading Factor (SLF) value of the indicators of latent variable in the measurement model of historical awareness has met the requirements; SLF is significantly higher than 0.3 , with the t-value higher than 1.96 at the significance level of $95 \%$.

Table 4. Test item distribution of historical awareness instrument

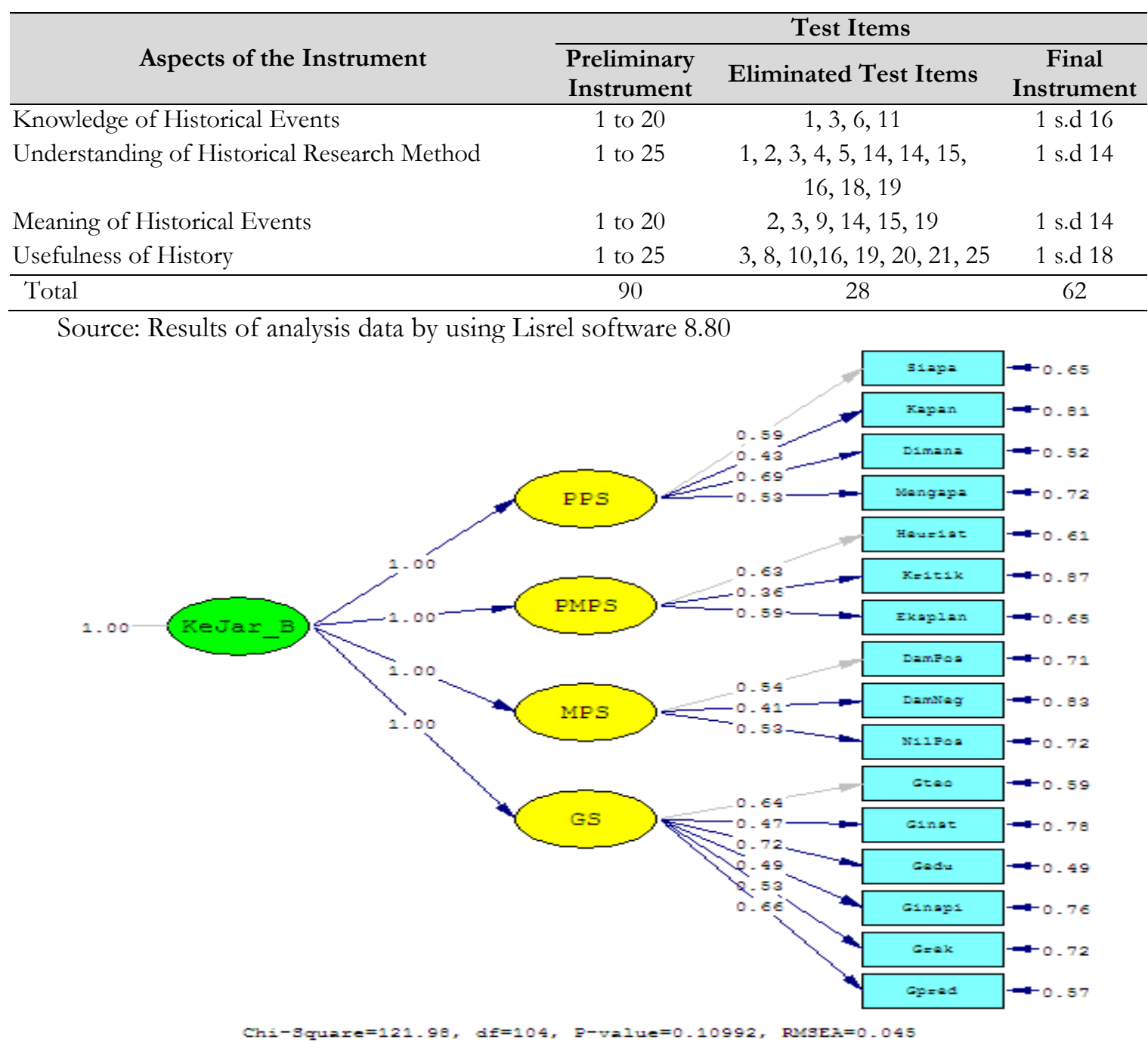

Figure 3. Historical awareness measurement model resulted from the empirical testing (Standardized) 
Table 5 shows the value of the loading factor in each indicator that has passed the empirical testing process. Overall, the loading factor values of all indicators range from 0.36 to 0.72 . The lowest loading factor value is shown by the 'kritik' indicator of the PMPS latent variable (0.36), while the highest loading factor value is found in the 'Gedu' (educational usefulness) indicator from the GS latent variable (0.72). The t-value of all indicators ranges from 2.99 to 5.54 (> 1.96). Therefore, it can be stated that the measurement instrument of historical awareness in the form of associative multiple-choice test items has good construct validity and is valid for measuring historical awareness.

The reliability of the measurement model of historical awareness is shown by the coefficient of Composite Reliability (CR). The composite reliability is known as multidimensional reliability because the measured constructs are multidimensional and based on the confirmatory factor analysis. The coefficient of composite reliability explains the value of the indicator proportion in explaining the measured constructs (Margono, 2013, p.19). A study by Widhiarso \& Mardapi (2010, p.17) proves that the coefficient of composite reliability had high accuracy in the multidimensional model.

The estimation of the coefficient of composite reliability for the constructs of historical awareness measurement model in Table 5 ranges from 0.6 to 0.8 . These coefficients are acceptable as long as the validity indicators of the model constructs are good

Table 5. The validity and reliability of the instrument construct

\begin{tabular}{|c|c|c|c|c|c|c|}
\hline \multirow{2}{*}{\multicolumn{2}{|c|}{ Factor and Indicator }} & \multicolumn{2}{|c|}{$2^{\text {nd }}$ Order CFA } & \multirow{2}{*}{$\begin{array}{l}\text { Construct } \\
\text { Validity }\end{array}$} & \multicolumn{2}{|c|}{ Construct Reliability } \\
\hline & & SLF* & t-value & & CR & Decision \\
\hline \multirow[t]{4}{*}{ PPS } & Siapa & 0.59 & $* *$ & Good & \multirow{4}{*}{0.7} & \multirow{4}{*}{ Good } \\
\hline & Kapan & 0.43 & 3.48 & Good & & \\
\hline & Dimana & 0.69 & 5.02 & Good & & \\
\hline & Mengapa & 0.53 & 4.10 & Good & & \\
\hline \multirow[t]{3}{*}{ PMPS } & Heuristik & 0.63 & $* *$ & Good & \multirow{3}{*}{0.7} & \multirow{3}{*}{ Good } \\
\hline & Kritik & 0.36 & 2.99 & Good & & \\
\hline & Eksplanasi & 0.59 & 4.68 & Good & & \\
\hline \multirow[t]{3}{*}{ MPS } & DamPos & 0.54 & $* *$ & Good & \multirow{3}{*}{0.6} & \multirow{3}{*}{ Acceptable } \\
\hline & DamNeg & 0.41 & 3.16 & Good & & \\
\hline & NilPos & 0.53 & 3.86 & Good & & \\
\hline \multirow[t]{6}{*}{ GS } & Gteo & 0.64 & $* *$ & Good & \multirow{6}{*}{0.8} & \multirow{6}{*}{ Good } \\
\hline & Ginst & 0.47 & 3.89 & Good & & \\
\hline & Gedu & 0.72 & 5.54 & Good & & \\
\hline & Ginspi & 0.49 & 4.05 & Good & & \\
\hline & Grek & 0.53 & 4.29 & Good & & \\
\hline & Gpred & 0.66 & 5.16 & Good & & \\
\hline
\end{tabular}

Source : Results of data analyzed with Lisrel 8.8 software

*SLF : Standardized Loading Factor

** : Defined by default by Lisrel, t-value was not estimated

CR : Composite Reliability

Table 6. Results of overall goodness of fit model of historical awareness instrument

\begin{tabular}{cccc}
\hline GOF & Targeted Score & Attained Score & Note \\
\hline$\chi^{2}$ statistics & Expected to be small & 121.98 & Expected to be small \\
$\chi^{2}$ probability $(p$-value $)$ & $\geq 0.05$ & 0.101 & Good \\
RMSE $A$ & $\leq 0.08$ & 0.045 & Good \\
GFI & $\leq 0.90$ & 0.85 & Good \\
AGFI & $\geq 0.90$ & 0.84 & Quite good \\
CFI & $\geq 0.90$ & 0.96 & Good \\
NFI & $\geq 0.90$ & 0.89 & Good \\
\hline
\end{tabular}

Source: Results of data analyzed with Lisrel 8.80 software 
(Hair et al., 2009, p.688). The coefficient of CR for the dimension of PPS and of PMPS is equal to 0.7 , the coefficient of CR for the dimension of MPS is equal to 0.6 and the coefficient of CR for the dimension of GS is equal to 0.8 . Therefore, it can be stated that the measurement instrument of historical awareness might provide reliable or trustworthy results.

The results of overall goodness of fit of the model show that the developed measurement model of historical awareness theoretically is supported by empirical data. The results of overall goodness of fit of the model is presented in Table 6 .

\section{Conclusions}

The results of the study show that the developed measurement model of historical awareness is valid and reliable and fit to the empirical data. The constructs of the measurement model of historical awareness consist of four dimensions i.e. the knowledge of historical events, understanding of historical research method, the meaning of historical events, and the usefulness of history. The validity of the measurement model shown by the validity of test instrument constructs and the loading factor values of all indicators in the measurement model of historical awareness ranges from 0.36 to 0.72 . The reliability of the measurement model of historical awareness is shown by the coefficient of composite reliability (CR) that ranges from 0.6 to 0.8 . The empirical testing of fit of the model shows that the model is fit, with the $\chi^{2}$ value of 121.98, the p-value of 0.11 and RMSEA of 0.043 . Thereby, it can be concluded that the developed measurement model of historical awareness is supported by empirical data.

\section{References}

Allen, M. J., \& Yen, W.M. (1979). Introduction to measurement theory. Monterey, CA: Brooks/ Cole.

Ankersmit, F.R. (1987). Refleksi tentang sejarah: Pendapat-pendapat modern tentang filsafat sejarah [Reflection on history: Modern opinions on historical philosophy]. (D. Hartoko, Trans.). Jakarta: Gramedia.
Ata, B. (2009). The Turkish prospective history teachers' understanding of analogy in history education. International Journal of Historical Learning, Teaching and Research, 8(1), 6-18.

Barash, J. A. (2003). Martin Hiedegger and problem of historical meaning. New York, NY: Fordham University Press.

Cohen, M. R. (1961). The meaning of buman history. Chicago, IL: The Open Court.

Denison, B. J. (2011). History, time, meaning and memory: Idea for sociology of religious. Leiden: Koninklijke Brill NV.

Elliott, J. (2003). The limits of historical knowledge. European Review, 11(1), 21 25. doi:10.1017/S1062798703000036

Ghozali, I. (2008). Structual equation modeling: Teori, konsep, dan aplikasi. Semarang: Badan Penerbit Universitas Diponegoro.

Gleencross, A. (2010, October). Historical awareness in international relation theory: $A$ bidden disciplinary dialogue. Paper presented in millennium conference at Universitas Berden.

Gottschalk, L. (1956). Understanding history: $A$ premier of historical method. New York, NY: Alfred A. Knopf.

Grant, S.G. (2003). History lessons: Teaching, learning, and testing in US high school classrooms. Mahwah, NJ: Lawrence Erlbaum Associate.

Greenberg, D. (1991). Metahistory of everyday: Historical awareness in lived existence (set in late eighteenth century Britain) (Unpublished master's thesis). University of British Columbia, Canada.

Hair, J.F., Black, W.C., Babin, B.J., \& Anderson, R.E. (2009). Multivariate data analysis ( $7^{\text {th }}$ ed.). Upper Saddle River, NJ: Prentice Hall.

Hariyono. (1995). Mempelajari sejarah secara efektif. Jakarta: Pustaka Jaya.

Heller, A. (1982). A theory of history. London: Routledge \& Keagan Paul. 
Hendryadi. (2014). Structural equation modeling dengan Lisrel 8.80: Pedoman untuk pemula. Yogyakarta: Kaukaba.

Husband, C., Kitson A., \& Pendry, A. (2003). Understanding history teaching. Philadelphia, PA: Open Universitu Press.

Ministry of Education and Culture. (2012). Pemikiran tentang pembinaan kesadar-an sejarah.

Kartodirdjo. (1986). Ungkapan-ungkapan filsafat sejarab Barat dan Timur: Penjelasan berdasarkan kesadaran sejarah. Jakarta: Gramedia.

Kartodirdjo. (1992). Pendekatan ilmu sosial dalam metodologi sejarah. Jakarta: Gramedia Pustaka Utama.

Kartodirdjo. (1993). Pembangunan bangsa. Yogyakarta: Aditya Media.

Khine (ed.). (2013). Contemporary approaches to research in learning innovations: Application of structural equation modeling in educational research and practice. Rotterdam: Sense.

Kitson, A., Husbands, C., \& Steward, S. (2011). Teaching and learning history 11-18: Understanding the past. New York, NY: Open University Press McGraw-Hill Education.

Kolbl, C. \& Straub, J. (2001). Historical consciousness in youth. Theoretical and exemplary empirical analyses. Forum Qualitative Sozialforschung / Forum: Qualitative Social Research, 2(3). Retrieved from http://www.qualitative-research. net/index.php/fqs/article/view/904.

Korber, A. (2015). Historical awareness, historical competencies - and beyond? Some conceptual development within German history didactics. 56 S, URN: urn:nbn:de:0111-pedocs108118.

Kreuzer, M. (2010). Historical knowledge and quantitative analysis: The case of the origins of proportional representation. American Political Science Review, 104(2), 369-392.

Kuntowijoyo. (2013). Pengantar ilmu sejarah. Yogyakarta: Tiara Wacana.
Kusnendi. (2008.) Model-model persamaan struktural. Bandung: Alfabeta.

Latief, J. A. (2006). Manusia, filsafat dan sejarah. Jakarta: Bumi Aksara.

Lukacs, J. (1968). Historical awareness: Remembered past. New York, NY: Harper \& Row.

Mardapi, D. (2007). Teknik penyusunan instrumen tes dan nontes. Yogyakarta: Mitra Cendikia.

Mardapi, D. (2012). Pengukuran, penilaian dan evaluasi pendidikan. Yogyakarta: Nuha Medika.

Margono, D. (2013). Aplikasi analisis faktor konformatori untuk menentukan reliabilitas multidimensi. Statistika, 13(1), 17-24.

Mazabow, G. (2003). The development of historical awareness in the teaching of history in South Africa School (Unpublished doctoral dissertation). University of South Africa, Pretoria.

Paska, L. M. (2010). Does film affect learning engangement?: historical inquiry and the document-based question in middle school social studies classroom (Unpublished doctoral dissertation). Albany University, New York, NY.

Plomp, T. \& van de Wolde, J. (1982). The general model for systematical problem solving. In T. Plomp (Eds.). Design of educational and training (in Dutch). Utrecht: Lemma. Netherland. Faculty of Educational Science and Technology, University of Twente. Enschede the Netherlands.

Pompa, L. (1990). Human nature and historical knowledge: Hume, Hegel and Vico. Cambridge: Cambridge University Press.

Rosenlund, D. (2011). Subject construction, assessment and aligment in history education. Paper presented at the $39^{\text {th }}$ Congres of NPFP/NERA in Malmo University, Malmo, Sweden.

Russel, W.B. \& Pellegrino, A. (2008). Constructing meaning from historical 
content: A research study. Journal of Social Studies Research, 32(2), 3-15.

Schumacker, R.E., \& Lomax, R.G. (2010). A beginner's guide to structural equation modeling. $\quad\left(3^{\text {rd }}\right.$ ed.). New York, NY: Routledge.

Sjamsuddin, H. (2012). Metodologi sejarah. Yogyakarta: Ombak.

Suhartono. (2010). Teori dan metodologi sejarah. Yogyakarta: Graha Ilmu.

Thorp, R. (2014). Historical awareness, historical media, and history education. Historiska medier. ISBN 978-91-7601077-8 [electronic version].

Topolski, J. (1976). Methodology of history. (O. Wojta-siewicz, Trans.). Boston, MA: D. Reidel.

Tosh, J. (1984). The pursuit of history: Aim, method, and new directions in the study of modern history ( $1^{\text {rd }}$ ed.). New York, NY: Longman.
Tosh, J. (2002). The pursuit of history: Aim, method, and new directions in the study of modern history ( $3^{\text {rd }}$ ed.). London: Longman Pearson Education.

Tucker, A. (Eds). (2009). A companion to the philosophy of history and historiography. Chihester West Sussex: Blackwell.

Widhiarso, W. \& Mardapi, D. (2010). Komparasi ketepatan estimasi koefisien reliabilitas teori skor murni klasik.Jurnal Penelitian dan Evaluasi Pendidikan, 14(1). Retrieved from http://journal.uny.ac.id/index.php/jpe $\mathrm{p} /$ article/view/1973.

Wineburg, S. (2006). Berpikir historis: Memetakan masa depan mengajarkan masa lalu. (M. Maris, Trans.). Philadelphia, PA: Temple University.

Wijanto. S.H. (2008). Structural equation modeling dengan lisrel 8.8: Konsep \& tutorial. Yogyakarta: Graha Ilmu. 